\title{
Greenbug, Schizaphis graminum (Rondani) (Insecta: Heteroptera: Aphididae) $)^{1}$
}

Gregg S. Nuessly and Russell T. Nagata ${ }^{2}$

\section{Introduction}

The greenbug, Schizaphis graminum (Rondani), has been recognized as a major pest of small grains for over 150 years. Described by Rondani, it was first placed in the genus Aphis (Rondani 1852) and later moved to the genus Toxoptera. There are about 40 recognized Schizaphis species worldwide with seven known from North America (Blackman and Eastop 2000).

The first North American report of greenbug was on wheat and barley in Virginia about 1882 (Webster $\&$ Phillips 1912). Both winter and spring grains can be severely damaged by greenbug populations. In early 1968, a biotype that caused severe damage to grain sorghum became common in Nebraska and soon spread throughout grain producing areas of North America (Harvey and Hackerott 1969). Nine greenbug biotypes that damage small grains have now been identified. In 1970, greenbug was first discovered feeding on and damaging Kentucky bluegrass (Street et al. 1978). This biotype has now spread into many Midwestern US states. Schizaphis graminum was discovered colonizing and damaging a new turfgrass host, seashore paspalum $\mathrm{cv}$ SeaDwarf' (Paspalum vaginatum Swartz), in Belle Glade, Florida in November 2003 (Nuessly et al. 2004).

\section{Distribution}

The greenbug is thought to be palearctic in origin and is now found in North, Central and South America, Europe, Africa, the Middle East and Asia (Blackman and Eastop 2000). Winged greenbugs have been regularly collected in suction traps located across the Florida peninsula since a trapping study began in 1998 (Halbert \& Nuessly 2003).

\section{Life Cycle and Description}

Schizaphis graminum reproduces without mating (i.e., parthenogenesis) in warm or mild climates. Females mate with winged males in areas with cold winters to produce overwintering eggs mostly on Poa pratensis. Nymphs are produced directly from the female in Florida. Greenbugs pass through three instars directly into the adult stage (i.e., no pupal stage) in seven to nine days at temperatures of 60 to

1. This document is EENY-353, one of a series of Featured Creatures from the Entomology and Nematology Department, Florida Cooperative Extension Service, Institute of Food and Agricultural Sciences, University of Florida. Published: July 2005. This document is also available on Featured Creatures Website at http://creatures.ifas.ufl.edu. Please visit the EDIS Website at http://edis.ifas.ufl.edu.

2. Gregg S. Nuessly and Russell T. Nagata, Entomology and Nematology Department, Institute of Food and Agricultural Sciences, University of Florida, Belle Glade, FL.

The Institute of Food and Agricultural Sciences (IFAS) is an Equal Opportunity Institution authorized to provide research, educational information and other services only to individuals and institutions that function with non-discrimination with respect to race, creed, color, religion, age, disability, sex, sexual orientation, marital status, national origin, political opinions or affiliations. U.S. Department of Agriculture, Cooperative Extension Service, University of Florida, IFAS, Florida A. \& M. University Cooperative Extension Program, and Boards of County Commissioners Cooperating. Larry Arrington, Dean 
$80^{\circ} \mathrm{F}$. Adult greenbugs produce one to five nymphs per day on seashore paspalum.

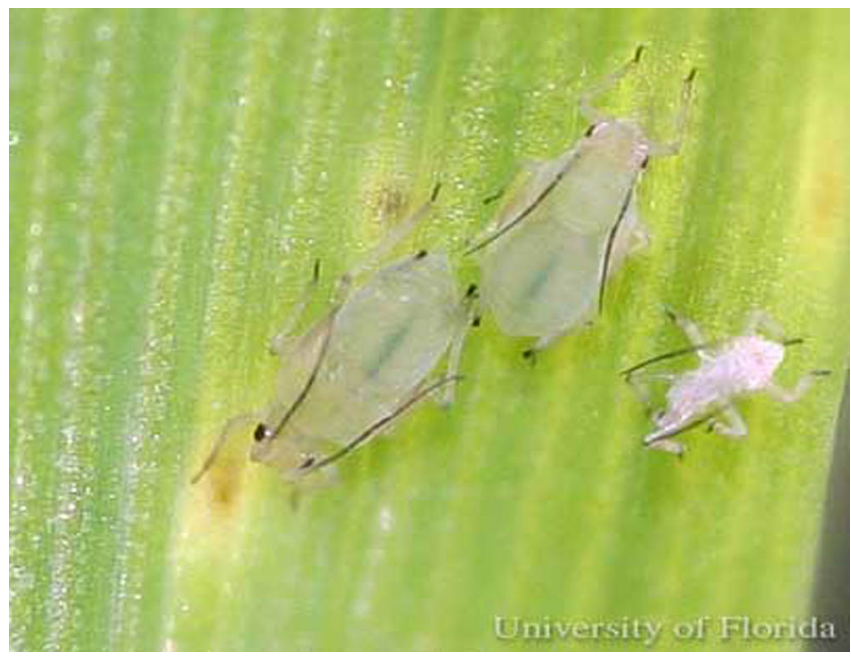

Figure 1. Immature greenbugs, Schizaphis graminum (Rondani), on seashore paspalum. Credits: Gregg S. Nuessly, University of Florida

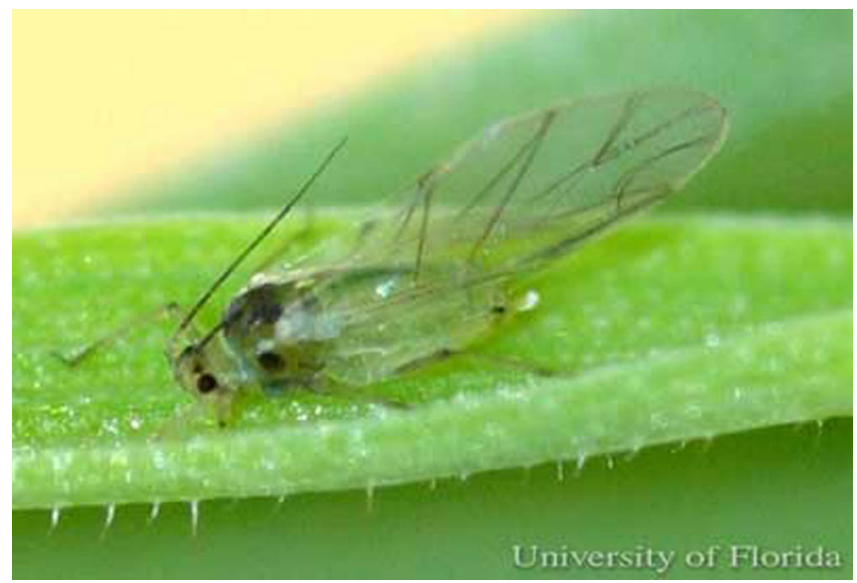

Figure 2. Winged adult greenbug, Schizaphis graminum (Rondani), on seashore paspalum. Credits: Gregg S. Nuessly, University of Florida

Greenbugs are small (1.3 to $2.1 \mathrm{~mm}$ ), elongate oval shaped aphids with head and first part of thorax straw to pale green and with light to medium green abdomen. A darker green stripe down the middle of the top surface of the abdomen is most visible on last instar nymphs and adults. The antennae are uniformly dusky. The cornicles or siphunculi are pale with slightly flared and darkened tips. Winged aphids are produced as crowding and damage symptoms increase.

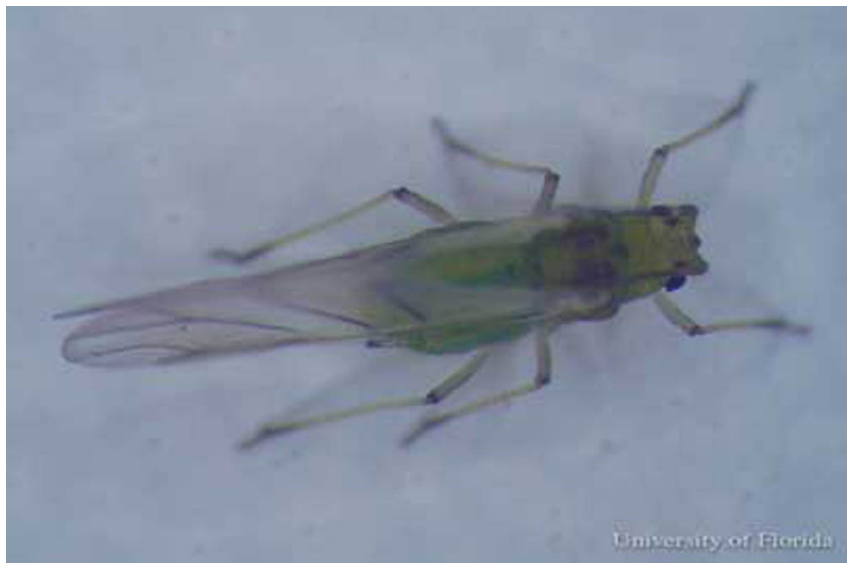

Figure 3. Winged adult greenbug, Schizaphis graminum (Rondani). Credits: Russell T. Nagata, University of Florida

\section{Host Plants}

The host range of greenbug includes 70 graminaceous species (Michels 1986). The aphid develops on species in the genera Agropyron (wheatgrass), Avena (oat), Bromus, Dactylis, Eleusine, Festuca (fescue), Hordeum (barley), Lolium, Oryza (rice), Panicum, Paspalum, Poa, Sorghum (sorghum), Triticum (wheat) and Zea (maize).

\section{Damage}

Greenbug saliva has enzymatic activity that breaks down cell walls and chloroplasts in susceptible plants (Al-Mousawi et al. 1983). Feeding by greenbugs initially causes yellow or red leaf spots. Continued feeding leads to general yellowing and reddening, leaf and root death, and can lead to plant death. Plant size, yield and survival are greatly affected by greenbugs feeding on susceptible small grain cultivars.

On seashore paspalum turfgrass, the aphid feeds and reproduces on leaves and stems, but prefers locations along the midrib of the upper leaf surface. Feeding results first in a small yellow chlorotic spot surrounded within $24 \mathrm{hr}$ by a ring of water-soaked tissue. The spots enlarge, become brighter yellow and coalesce with other feeding spots within a few days. The midrib becomes necrotic as the spots cover the majority of the leaf surface. Feeding near the ends of leaves results in characteristic brown necrotic leaf tips bordered below by bright yellow bands. These 
damaged tips present an obvious contrast to the rich green color of 'SeaDwarf.' Aphids vacate heavily damaged leaves in favor of green leaves. Turfgrass damage progresses as the colony expands outward with loss of acceptable foliage. Heavily damaged patches of turfgrass appear thin or sparsely planted with little green tissue. Greenbugs do not produce noticeable amounts of honeydew when feeding on seashore paspalum. Therefore, the leaves do not get sticky nor serve as a substrate for sooty mold growth as is usually found associated with grass-feeding aphids.

Greenbugs transmit plant viruses including barley yellow dwarf (Murphy 1959), sugarcane mosaic (Ingram \& Summers 1938) and maize dwarf mosaic (Nault \& Bradley 1969).

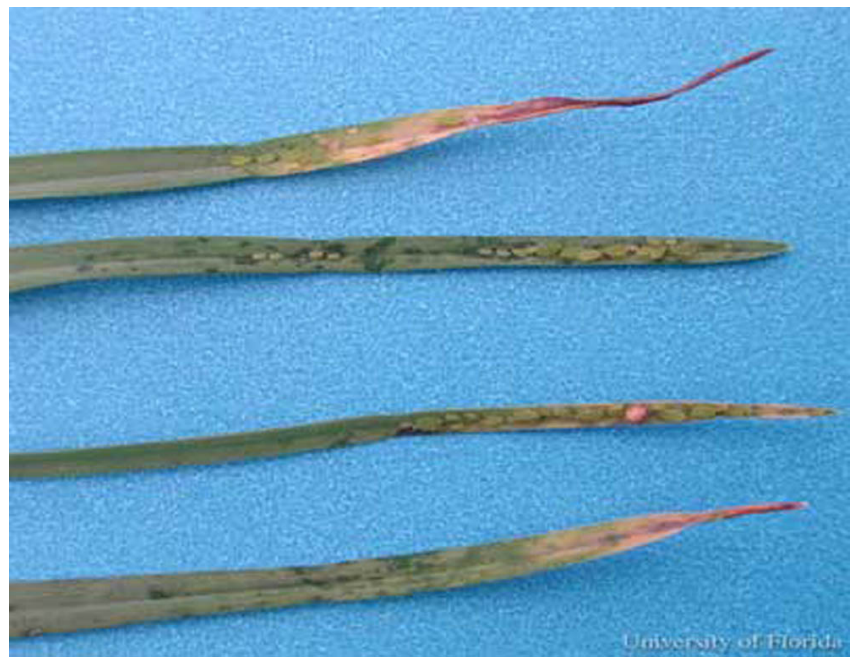

Figure 4. Greenbug, Schizaphis graminum (Rondani), damage symptoms on seashore paspalum turfgrass. Note small chlorotic spits surrounded by water soaked spots on both leaves. Reddish spots and necrotic tissue result after only four days of feeding. Credits: Russell T. Nagata, University of Florida

\section{Natural Enemies}

Ladybird beetle adults and larvae (Coccinellidae), flower fly larvae (Syrphidae), lacewings (Chrysopidae and Hemerobiidae), ground beetles (Carabidae), parasitic wasps, spiders and fungal pathogens all have a regulating effect on greenbug populations. However, greenbug develops and reproduces faster at lower temperatures than do their natural enemies, which allows them to reach damaging levels early in the season before natural enemies can reach their potential.

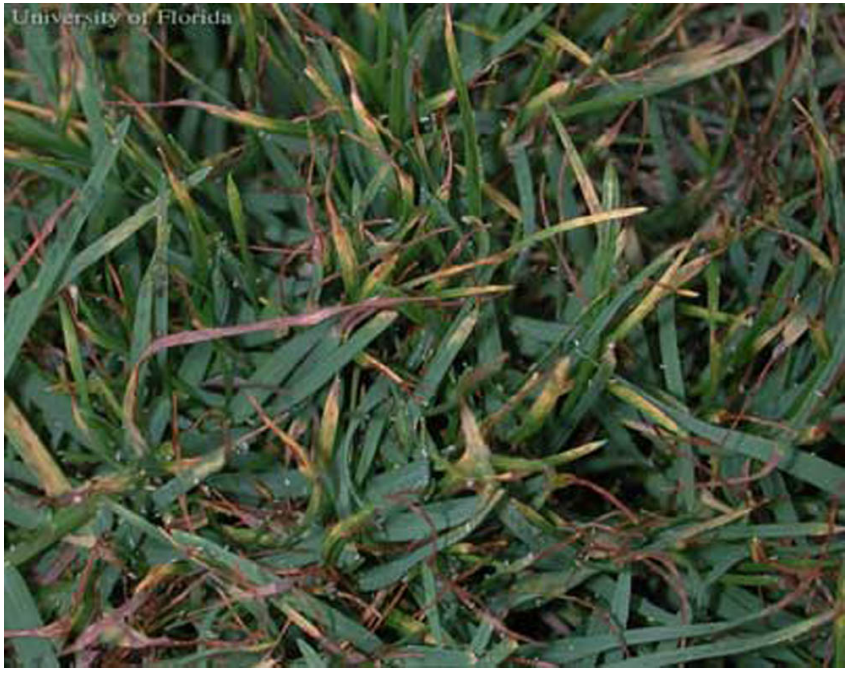

Figure 5. Damage symptoms from greenbug, Schizaphis graminum (Rondani), feeding on seashore paspalum turfgrass. Note yellow, red and dead leaf tips. Molted 'skins' of aphids are visible as small white spots throughout this image. Credits: Russell T. Nagata, University of Florida

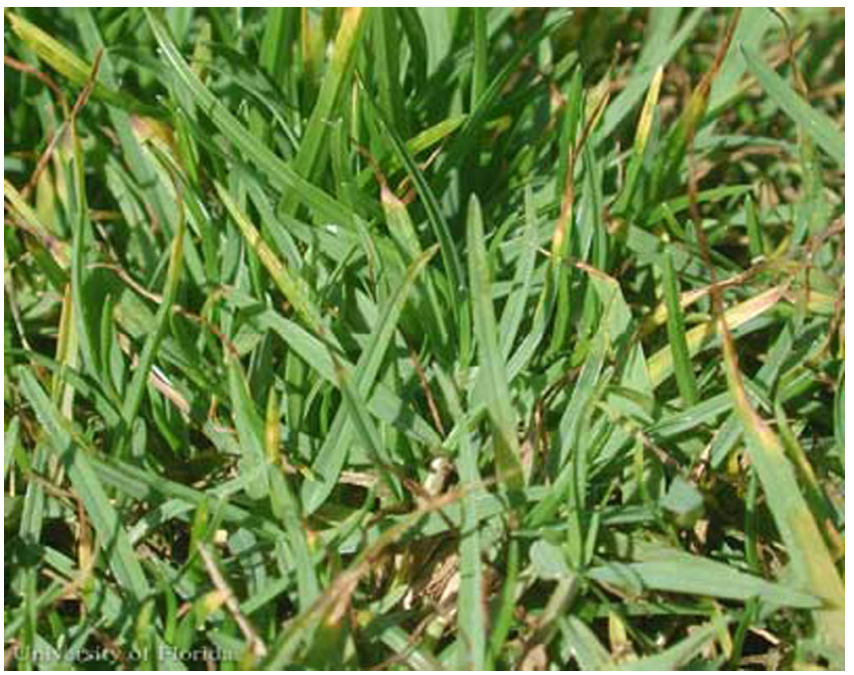

Figure 6. Damage symptoms from greenbug, Schizaphis graminum (Rondani), feeding on seashore paspalum turfgrass. Credits: Gregg S. Nuessly, University of Florida

\section{Management}

Insecticides are the front line defense against greenbugs in small grain crops (Hays et al. 1999), but the more economical solution is host plant resistance. Cultivars have been developed with resistance to one or more greenbug biotypes. Because most resistant lines are tolerant of greenbug feeding, small numbers of greenbugs may still be present on these resistant cultivars. Small grain fields should be checked regularly from seedling emergence to tillering. Leaves with yellow or red discolorations should be 


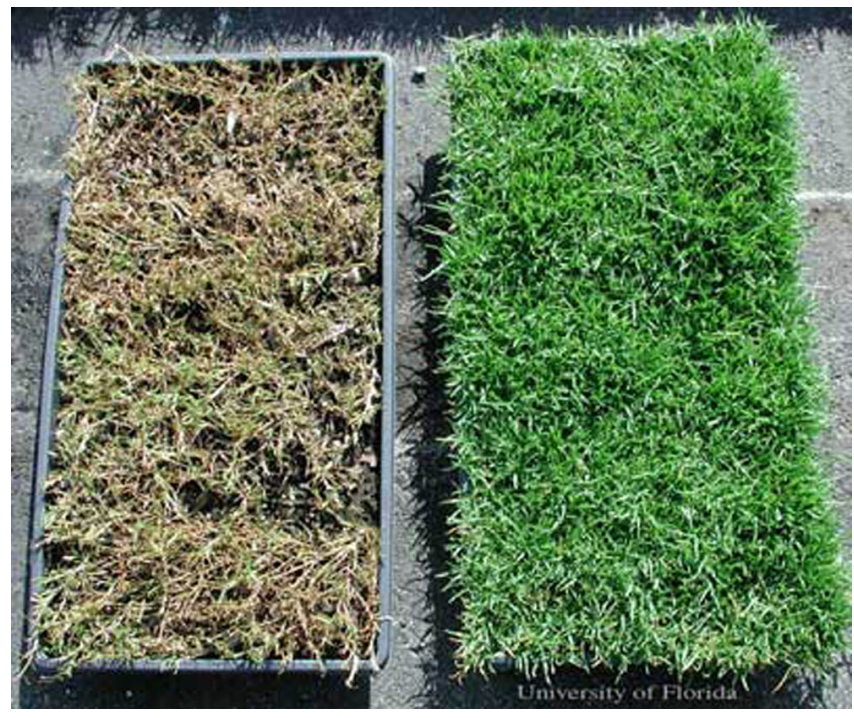

Figure 7. Prolonged greenbug, Schizaphis graminum (Rondani), feeding damage to seashore paspalum turfgrass (left tray). Credits: Russell T. Nagata, University of Florida

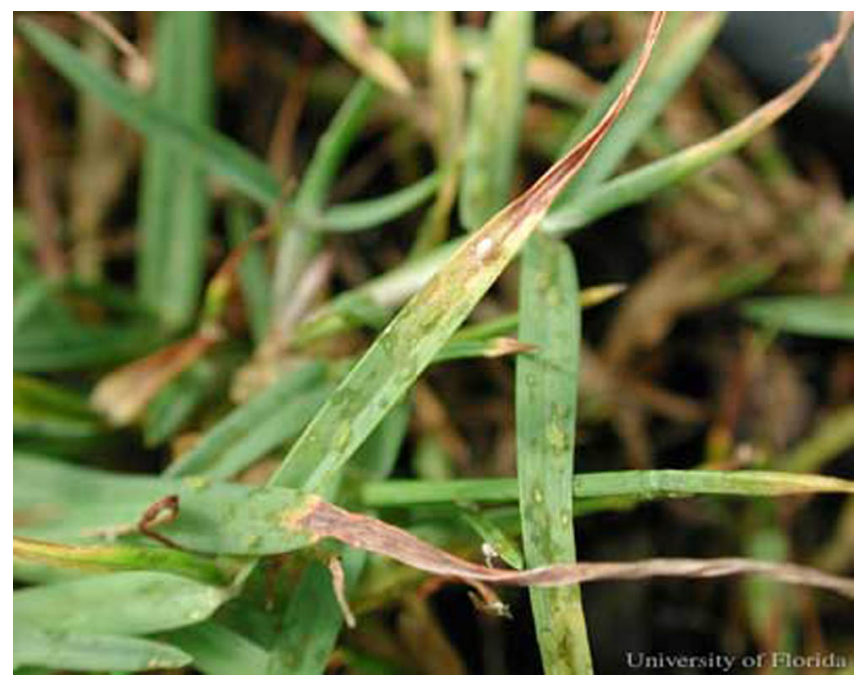

Figure 8. Greenbug, Schizaphis graminum (Rondani), aphid 'mummy' (parasitized aphid) on seashore paspalum turfgrass. Credits: Russell T. Nagata, University of Florida

examined closely for the presence of the aphid. Greenbugs feed on the underside of small grain leaves. Apply an insecticide if greenbug is present in large numbers and discoloration is evident before tillering. Drought stressed plants are more susceptible to greenbug damage than adequately irrigated crops. Prolonged temperatures over $85^{\circ} \mathrm{F}$ have a negative effect on reproduction and survival of greenbugs. Natural enemies also are better able to keep up with these aphids at warmer temperatures. Insecticide applications can be postponed or prevented if more than $20 \%$ of the greenbugs are swollen and have a light brown, papery appearance due to parasitism (Cronholm et al. 1998).

For more management information please see, Insect Management Guide for Field Crops (http://edis.ifas.ufl.edu/TOPIC_GUIDE_IG_ Field_Crops_and_Pastures).

Greenbugs have been found on seashore paspalum turfgrass from Avon Park, Florida south into Miami/Dade County. Frequently mowed and low cropped areas on golf courses, such as greens, tee's and fairways, are not favored by the aphids. The roughs and other less frequently mowed areas around buildings or landscaping around seashore paspalum golf courses, parks or common areas should be monitored for blade discoloration during the late fall through spring months. Early damage symptoms are easier to observe before mid morning or after mid afternoon with the sun at your back. Yellowing of leaves is often mistaken for irrigation or fertilization problems. Although greenbugs prefer to feed on the top surface of seashore paspalum, the folded nature of the leaf blades and the aphid's color and small size make them difficult to see. Aphids on turfgrass can be detected by wetting your hand and then pressing it into the turf in several spots within the suspected area. Greenbugs will be visible as straw to medium green colored spots on your hand. Greenbugs move from yellowing blades onto healthier green tissue, so look for aphids on the edges of spots where grass has already been severely damaged.

Liquid formulations of insecticides registered for use in turfgrass are effective at controlling greenbugs (Nuessly \& Nagata 2005). Insecticides applied as granules move downward into the thatch away from the greenbug's preferred feeding area up on the blades and are thus ineffective at controlling this aphid. Area treated should be at least six feet beyond the edge of the turfgrass showing damage symptoms. Greenbug is likely to have spread to another nearby area of the course or park by the time they are diagnosed. Therefore, careful scouting to find and treat all the affected areas is important to reduce the chance for re-introduction or further spread. 


\section{Selected References}

Al-Mousawi AH, Richardson PE, Burton RL. 1983. Ultrastructural studies on greenbug (Hemiptera: Aphididae) feeding damage to susceptible and resistant wheat cultivars. Annals of the Entomological Society America 71: 964-971.

Blackman RL, Eastop VF. 2000. Aphids on the World's Crops, An Identification and Information Guide, 2nd Edition. John Wiley \& Sons Ltd., England.

Cronholm G, Knutson A, Parker R, Teetes G, Pendleton B. 1998. B-1220 Managing Insect and Mite Pests of Texas Sorghum. Texas Agricultural Extension Service. The Texas A\&M University System. http://insects.tamu.edu/extension/ publications/html/b-1220/B1220.html (18 July 2005).

Halbert SE, Nuessly GS. 2003. Species composition of Florida aphid fauna. In Aphids in a New Millenium. Simon JC, Dedryver CA, Rispe C, Hulle M [eds], Proceedings VIth International Symposium on Aphids. INRA Editions, Paris, France.

Harvey TL, Hackerott HL. 1969. Recognition of a greenbug biotype injurious to sorghum. Journal of Economic Entomology 62: 776-779.

Hays DB, Porter DR, Webster JA, Carver BF. 1999. Feeding behavior of biotypes $\mathrm{E}$ and $\mathrm{H}$ greenbug (Homoptera: Aphididae) on previously infested near-isolines of barley. Journal of Economic Entomology 92: 1223-1229.

Ingram JW, Summers EM. 1938. Transmission of sugarcane mosaic by the greenbug (Toxoptera graminum Rond.). Journal of Agricultural Research 56: $537-540$.

Michels Jr GJ. 1986. Graminaceous North American host plants of the greenbug with notes on biotypes. Southwestern Entomologist 11: 55-66.

Murphy HC. 1959. The epidemic of barley yellow dwarf on oats in 1959: Introduction. Plant Disease Reporter Supplement 262: 316.

Nault LR, Bradley RHE. 1969. Acquisition of maize dwarf mosaic virus by the greenbug,
Schizaphis graminum. Annals of the Entomological Society America 62: 403-406.

Nuessly GS, Nagata RT, Beiriger RL, Scully BT, Halbert S. 2004. Aphid Damaging Seashore Paspalum. Florida Turf Digest Jan/Feb: 24.

Nuessly GS, Nagata RT. (2005). Evaluation of insecticides for control of greenbug on seashore paspalum, 2004. Arthropod Management Tests, Entomological Society of America, http://www.entsoc.org/ (30 June 2005).

Rondani C. 1852. Aphis graminum n. sp. Nuove Ann. Sci. Nat. Bologna. 6: 9-11.

Street JR, Randell R, Clayton G. 1978. Greenbug damage found on Kentucky bluegrass. Weeds, Trees and Turf 17: 26.

Webster FM, Phillips WJ. 1912. The spring grain aphis or "greenbug." U.S. Bureau Entomological Bulletin 110. 153 pp. 